\title{
The Social Work Education in Turkey
}

\author{
İshak Aydemir ${ }^{1, *}$, Talip Yiğit ${ }^{2}$ \\ ${ }^{1}$ Department of Social Work, Bahçeşehir University, Turkey \\ ${ }^{2}$ Department of Social Work, İstanbul 29 Mayıs University, Turkey
}

\begin{abstract}
The aim of this study is to inform social workers working in the field, Social Work professional communities (national and international), professionals from other disciplines and social work students, about the history of social work education in Turkey, its' educational levels, curriculum structure, duration, application requirements and immediate situation and future, besides to increase their knowledge about being aware of the risks of the future of the profession. Social work education in the world started in the United States and European countries in early 1900s while in Turkey it started in 1961. The Academy of Social Work which was founded under the Ministry of Health and Social Aid in 1961 graduated its first class in 1965. Another department was also started within Hacettepe University in 1967 and in 1983. The two departments were merged under the name of Social Work College in Hacettepe University. Hacettepe University Social Work College has the feature of being the only department training in the field of social work from 1983 to 2002. The second social work education department was opened under Baskent University in Ankara and has the feature of being the first social work education department among private universities. Social work education which was started in 1961 was given at the level of bachelor degree until 2002 in Turkey. Since 1983, master's degree (opened in 1983) and doctoral program (opened in 1987) of "Social Work" were opened in the Department of Social Work under the Institute of Social Sciences at Hacettepe University (Karataş \& Erkan, 2005) and has graduated many students until today. That the number of masters and doctoral programs remain limited with only one university caused to fall behind to meet the needs of academicians. Today in Turkey, social work education is given at associate, bachelor's (formal education and open education), master and doctoral degree. Currently there are 193 universities in Turkey. By the end June, 2017, 50 universities have two-year degree programs (Associate), 58 universities have bachelor's degree program as formal education and 21 universities have master's degree programs ( 17 of thesis, 9 of non-thesis) and 7 universities have doctoral programs. Social work education in Turkey universities is generic and its aim is to produce graduates with skills in a considerable range of practice settings. Issues such as, the
\end{abstract}

historical progress of social work education, the immediate situation of social work at associate, bachelor's, master's and doctoral degrees, application numbers, application requirements and its curriculum were dealt with. In the discussion part, social work education, the profession, social workers and the risk factors believed to affect the future of the profession were also discussed. In the conclusion part, a general assessment was made.

Keywords Social Work Education, Curriculum, Social Worker, Fieldwork

\section{Background of Social Work Education in Turkey}

Social work is a practice-based profession and an academic discipline that promotes social change and development, social cohesion, and the empowerment and liberation of people. Principles of social justice, human rights, collective responsibility and respect for diversities are central to social work. Underpinned by theories of social work, social sciences, humanities and indigenous knowledge, social work engages people and structures to address life challenges and enhance wellbeing (www.ifsw.org, 2017).

Social Work is a discipline that grew out of humanitarian and democratic ideals and its values are based on equality, worth, and dignity of all the people in the society (www.ifsw.org, 2017). At the onset of the 20th century, significant social problems such as industrialization and urbanization created a large vacuum of needs among poor families all over the nation (Gibelman, 1999; Tratter, 1998). Significant rifts emerged between many groups of people. Rich and poor, native-born and immigrants, and people of different religious faiths were adversely affected by rapid economic and social changes (Addams, 1893; Chandler, 1999). At the same time, social work began its emergence as a separate discipline from its sociology roots (NASW, 1995).

Social welfare institutions were launched with the attempts to meet the needs of people living in urban areas in 
1800s. These institutions or services are private organizations improved through the initiatives of their leaders and religious groups (Zastrow, 2010). Social work education was given firstly at the social work institutions of the period in the years the profession have emerged and continued to progress as a part of the education system of the country in which it takes place. Thus, the education is still realised in different organizations within different countries (Payne, 2005). Social work is focused on the improvement dynamics of human and public as a science; and as a profession it aims to increase the life quality of human (Uluğtekin et al., 2002: 10). It is certain that achieving its aim is primarily dependent on the professional competences of social workers who are the executives of the profession. Being a competent member of profession requires a qualified education which blended the knowledge, ability and values of the profession.

The social work education in the United States and in Europe started since the beginning of the 1900s. Social work education in the United States and Europe was given bachelor's degree in 14 universities in 1910. Social work education started in Latin America (Argentina and Chile) in 1920, South Africa in 1924, India in 1936 and Australia in 1940 (Rajendra, Venkat \& Channaveer, 2014; Karataş \& Erkan, 2005). In the 1960s, social work education was given in 150 schools in the USA and 41 schools in France (Payzin, 1961). According to the United Nations, social work education was given under social work department in 373 schools in 46 countries at the same period around the world (Sedky, 1961; Karataş \& Erkan, 2005).

Although the professional education of social work career has started in the world at the end of 19th century, it was launched in Turkey in 1961. Under the leadership of the United Nations' Social Welfare Commission, a meeting was held in 1957 in Turkey, aiming at reorganising current social work in Turkey with a scientific and professional approach with the participation of representatives of the Ministy of Health and Social Aid in the first place and then relavent ministry, public and private institutions. the Institute of Social Work was founded in 1959 in line with the decisions taken in that meeting for the purpose of doing research in the field in accordance with the law no 7355. The Academy of Social Work under the The Ministry of Health and Social Aid was founded in Ankara in 1961 in accordance with the law no 7355 (Çengelci, 1998; Koşar \& Tufan, 1999; Karataş \& Erkan, 2005; Duyan, 1996; Gökçeaslan, 2009; Aydemir \& Gökçeaslan, 2011).
The Academy of Social Work started to educate with 34 students in 1961 (Kuntbay, 1962), 341 candidates applied for the academic year 1961-1962 and 377 candidates for the academic year 1962-1963, intelligent and information tests were applied to candidates and according to ranking list by giving extra two (2) points to intelligent test, 75 students taking the highest score were invited to interview with the jury. Besides, tests related to social work were also planned and applied in the following years as well as intelligent and information tests (İyicil, 1963).

Today, students are accepted to social work departments according to the points they get from the Student Selection Examination (University Entrance Exam in Turkey). They are not subjected to any test or interview. Therefore, every student getting a passing rate can get into the department.

The Academy of Social Work became a member of the International Social Work Schools Association in 1966 and adapted its curriculum with social work curriculum given in world standards (Koşar \& Tufan, 1999). Morover, General Directorate of Social Work was also founded for practice under the Ministry of Health and Social Aid in 1963 (Duyan, 1996). The first scientific and professional social work practice in Turkey was launched at Hacettepe Hospital with a group of intern social worker under the guidance of Miss Bemmels in 1964 (Çakmaklı 1976). The Department of Social Work was opened in 1967 under the School of Economics and Administrative Sciences at Hacettepe University to train far more social workers in the field of social work.

With the legislative regulation made after the establishment of The Council of Higher Education (CHE) in 1983, the academy of social work and social work departments founded under Hacettepe University were merged and continued education at the level of bachelor's degree under the School of Social Work at Hacettepe University (Kut, 2005; Karataş \& Erkan, 2005). From 1983 to 2002 it has remained as the only school that continued to give social work education under Hacettepe University. The second social work department was set up under Baskent University in Ankara in 2002 and this department has the feature of being the first private university department opened. A politic-sociocultural climate has emerged towards setting up new social work departments in Turkey after 2002 (Alptekin, Topuz \& Zengin, 2014). Based on this conjuncture, social work departments have mushroomed and increased rapidly. 
Table 1. The distribution of social work departments by years

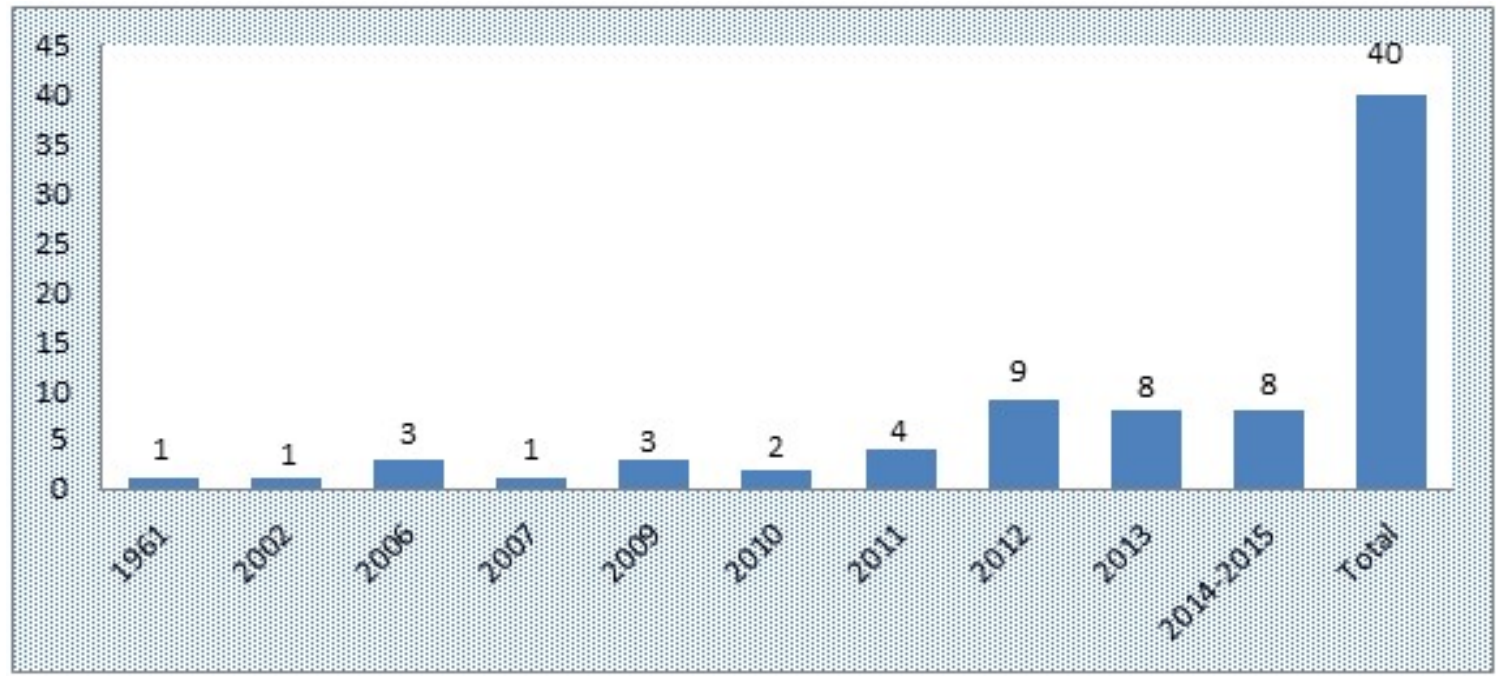

Social work departments were opened under different colleges and faculties. It is not necessary for social work departments to be connected to a faculty on opening. However, they can be opened under any college or faculty according to tendency of faculty members and administrative staff. In accordance with the Council for Higher Education Law, to open a faculty it is required to open at least three departments together under the same faculty. When three departments cannot be opened together it is opened as a college. For this reason, social work departments in some universities were opened as college status. But there is no difference between two of them in terms of curriculum and semester number. Graduates of either a college or a faculty can work as a social worker.

Please see the table below for the distribution of faculties and colleges in Turkey providing social work education at the level of bachelor degree.

Table 2. Profiles of Social Work Programmes (Bachelor's Degree)

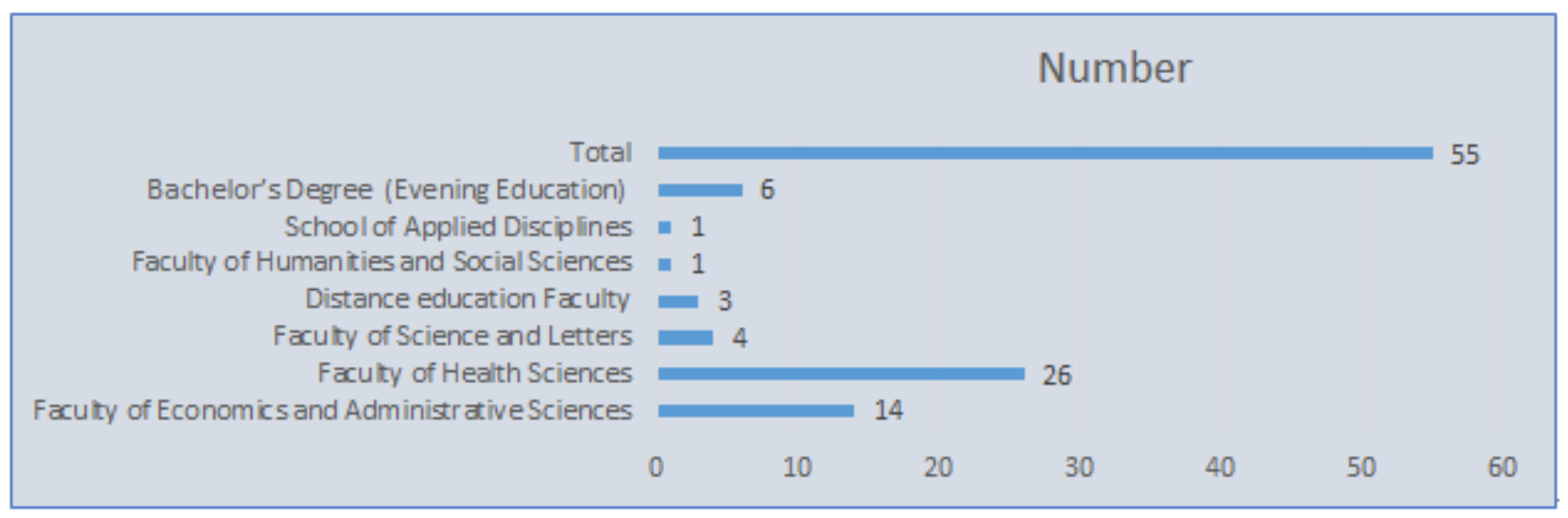

(Reference: Guidance for Student Selection and Higher Education Programs and Quotas, 2016).

In 1961, there was only one social work programme in Turkey. Over a period of 56 years the number of social work programmes has nearly 58. There are approximately 58 institutions providing social work education, spread over 193 universities in Turkey at the end of 2017.

Shown in table 3 is the general distribution of schools giving social work education in Turkey. Based on the table social work education is given at undergraduate, bachelor's (formal and distance education), master's and doctoral degrees. 
Table 3. Distribution of Schools giving Social Work Education

\begin{tabular}{|c|c|}
\hline Schools & Total \\
\hline $\begin{array}{c}\text { Two-Year Degree Programme (Open education 1 } \\
\text { Programs- Evening Education 10 Programs }\end{array}$ & 50 \\
\hline $\begin{array}{c}\text { Bachelor's Degree (Open education 2 Program - } \\
\text { Evening Education 7 Program }\end{array}$ & 58 \\
\hline Master Thesis & 17 \\
\hline Master's non-thesis & 9 \\
\hline Doctoral & 7 \\
\hline
\end{tabular}

(Reference: Guidance for Student Selection and Higher Education Programs and Quotas, July, 2017).

Currently there are 193 universities in Turkey. As it is seen in Table 3, 50 universities have two-year degree programs, 58 universities have bachelor's degree program as formal education and 26 universities have master's degree programs (17 of thesis, 9 of non-thesis) and 7 universities have doctoral programs.

Table 4. Estimated Number of Graduates of Social Work Programs

\begin{tabular}{|c|c|}
\hline Year & Estimated number of graduates \\
\hline 2016 & 9.867 \\
\hline 2017 & 14.243 \\
\hline 2018 & 19.351 \\
\hline 2019 & 25.461 \\
\hline 2020 & 31.571 \\
\hline 2021 & 37.681 \\
\hline 2022 & 43.791 \\
\hline 2023 & 49.901 \\
\hline
\end{tabular}

Note : Number of quotas 6,110 Students

The approximate numbers of graduates were given in Table 4 based on the quotas of existing social work education bachelor's degree programs. This number increases every year about seven thousand in average and is estimated to be around fifty thousand in 2023. It is considered that this increase may lead to employment problem in social work field. The public sector randomly calls for vacant job positions in recent years. This means that the graduates are confronted with unemployment problem. The most important reason for this situation is the increase in the number of social work departments opened in an unbalanced and uncontrolled way. These results are inevitable as these departments were opened without considering the ratio between supply and demand.

\section{Undergraduate Social Work Education}

Undergraduate programs consist of two years (four semesters). Two years undergraduate program was launched firstly in 2008-2009 academic year in Anatolian University in Turkey. Social work education is given in 23 universities in Turkey at undergraduate level. It is given as evening education in 9 of these universities. Undergraduate programs are not parallel with bachelor's programs in terms of content and practice. Each department prepares its curriculum and content separately. In 2016, 16,612 students enrolled in more than 23 recognized programs in the Turkey (2016 Guide for Assessment Selection and Placement Center). In 2017, 15,290 students will enroll in more than 50 recognized programs in the Turkey (2017 Guide for Assessment Selection and Placement Center). The great majority of the number is composed of open education programs (quotas 10,500). While the number of programs was 23 in 2016, the number of programs increased from 23 to 50 in 2017. That is, 27 departments were opened in 2017.

Social work education is given at bachelor's, master's and doctoral degree in accordance with the principles and standards of international social work education. Hence, opening an undergraduate program of social work education does not comply with the international standards. Although the content of undergraduate programs curriculum is tried to be prepared close to the curriculum of social work education programs, it is a known fact that the graduates of this program are not able to work with the applicants as social worker graduated at bachelor's degree.

\section{Bachelor's Degree Education}

As stated above, social work education at bachelor's degree was started in Turkey in 1961. Social work education at bachelor's degree continued to operate in its task to educate future social workers. The two social work schools were merged with the legal regulation in 1983 under the name of Social Work College in Hacettepe University and continued to provide Social Work education at bachelor's level. The bachelor of social work is the first professional degree for social work in Turkey. The main aim of the bachelor of social work degree is to equip the social work professionals with a generalist practice with individuals, families, groups, communities and organizations (micro, mezzo and macro levels). The minimum requirement for a professional position in the social work field is the bachelor's degree.

Social work education at bachelor's degree consists of four years ( 8 semesters) in Turkey. Theory based courses are generally given in the first three years. The practice is made either at third year level in some schools or at fourth year in some. Field practices are usually made twice a week in the first semester and five days a week in the second semester. Students perform their field practice at public, private or non-governmental organizations related with social work profession under the supervisorship of a social worker. Students are expected to focus on social work practice at micro level in the first semester. In the second semester, they are expected to actualize social work interference mainly at mezzo and macro level. Students cannot graduate without passing practice period. Practice comprises about one-third (approximately 1000 hours) of the four year program.

It is also mandatory to write a completion project in social 
work departments. Undergraduate thesis starts in some departments either at third or fourth grade. Completion project is produced as a group under the supervisorship of an academic adviser. The number of these groups consists of average 5-7 persons. These completion projects are prepared at bachelor's level diligently. The completion project is realized as the practice of research course in social work program.

Social work departments generally give education within the body of the faculty of health sciences, faculty of economics and administrative sciences, health colleges and faculty of science and letters. But a great majority of them give within the body of faculty of health sciences. The number of student admission quotas of these 49 departments in 2016 is about 6000 in 2016 Guide for Assessment Selection and Placement Center.

It is necessary to take required and elective courses at least 240 ECTS (European Credit Transfer and Accumulation System) to graduate from social work bachelor's degree programs. According to the Bologna process at least $25 \%$ of courses must be elective. Graduates of bachelor's degree get the title of social worker. In addition, social workers in Turkey are appointed as personnel of the class involved in the health service.

Social work education from 1961-1995 continued using the traditional methodology approach (Bulut, 2003). When the curriculum of the social work departments in Turkey were examined, in particular the most exemplary and outstanding programs among them (Ankara University, Baskent University, Kocaeli University, Hacettepe University, etc.) seem to have the following features: Course programs are generally prepared in a manner associated with each other, including theory and practice. In the first two years of four-year formal undergraduate education, it is mostly given basic theoretical courses which nourish the body of knowledge of social work discipline such as psychology, psychiatry, sociology, law, economics, anthropology, political science and public administration. The theoretical part of the courses consists of lectures related to understanding social work from many sides as a discipline and profession. These courses are taught with modern methods such as conference, group discussions, role playing and sample case analysis in line with available resources. The knowledge sets which of most important part stated below are included in the theory based courses:

- Human behavior and social environment

- Periods of human development

- Social structure and social change

- Culture, cultural competence and multiculturalism

- Democracy, human rights and social work.

- Social and economic justice

- Social problems

- Groups living under risk and pressure

- Gender and gender roles

- Family and group dynamics

- Crisis intervention
- Social welfare policy and social welfare services

- Social security applications

- Occupational health and safety

- Scientific research methods and techniques

- Verbal and nonverbal communication

- Contemporary theories in social services

- Social welfare and history of social services

- Social work ethics and values

- Conduct disorders, and social psychology

- Social service management, etc. (Alptekin, 2016).

In the third and fourth years of the program practice courses become more significant together with the courses related with the intervention methods of the profession. A major part of the field application courses is made in the third and fourth classes. Courses based on the field education have a weight ranging between $25 \%$ and $40 \%$. These courses are possible to be made in different provinces even abroad within the Erasmus program. Field practice is realized under the supervision monitoring (professional management) of one academic and one corporate adviser for students in order to make their studies at social work organizations regularly and planned in compliance with the basics of knowledge and value of social work. In fact supervision service realized by a competent social work academician to maintain to improve and develop knowledge and skills of students is run for every aspects of course program. Supervision provides students with a role model as well. For this reason supervision is one of the applications which puts a burden on academicians and is also critical and indispensable for putting into practice a social work program and also puts a burden on academicians.

Course program involves not only in-class training and field practice but also studies on project development and researches related to the subjects of social work field. Scientific research methods and techniques are of great importance in the program and include theories and applied courses. It is considered important to be given the theories and applied education in small groups by the supervision of academic staff which enables better communication. These courses aim to liberalize students, to provide them with self-confidence and the ability of interpersonal communication, to improve their problem solving competences and to get knowledge on the different areas they are interested in. The courses are based on the techniques of collaborative learning and students' active participation to the courses is supported.

Successive studies have been done about the competence and standards of social work education in Turkey since the early

2010s. The first of these studies is Core Competencies for Social Work Education prepared on the request of The Council of Higher Education within the context of studies of establishing a National Qualifications Framework for Higher Education which was launched in Bologna Process in 2005.

Social work education has been prepared for bachelor's, master's and doctoral degree by using ISCED (International 
Standard Classification of Education) identification codes of Core Competencies for Social Work Education concerning the studies on establishing the National Qualifications Framework for Higher Education in Turkey. ISCED presents standard concept, definition and classification. Social Work Bachelor's Degree Competencies were discussed in terms of knowledge and abilities based on the National Qualifications Framework for Higher Education in Turkey.

In addition, social work education is given at bachelor's degree as distance education in Turkey. Distance education system in our country has started its activities in Anatolia University since the 1982-83 academic year. As of today, there are distance education schools in three state universities, which are Anatolia, Istanbul and Erzurum Ataturk; only around 80,000 students are enrolled in the last two faculties. In contrast, in 2012 the number was over 208,000 students at Anadolu University.

$47 \%$ of our higher education system consists of distance education (Çetinsaya, 2014: 77-80). Social work education has been given with distance education method at Atatürk University since 2011 . The program quota was established as 1000 in the first year, as of the second year, this number has also increased. Currently Social Work Bachelor's Degree program was opened in Anadolu University in 2014 (the first year's quota is 500), and in Open Universities under Istanbul University in 2015.

Today, there are 193 universities in Turkey. There are a total of 84 social work departments, 58 of which are active and 26 are passive (that is; departments which have not accepted students yet). In 2017, 5,865 students will enroll in more than 58 recognized programs in the Turkey (2017 Guide for Assessment Selection and Placement Center). Open education programs quota consists of 2000 students, and evening education programs quota consists of 440 students. While the number of programs was 49 in 2016, the number of programs increased from 49 to 58 in 2017. That is, 9 social work programs were opened in 2017.

Social work has hampered the development of social work-based academicians because of the late opening of graduate and doctoral programs and the acceptance of very few students. Today, the number of academicians from social work is around 55 . This has been the biggest obstacle in meeting the academics' need for social work schools, which have been increasing dramatically since 2010 . The rapid increase in the number of undergraduate programs and the fact that the majority of the academicians from social service originate in these schools cause the students to graduate without qualification and without learning from the profession practitioners of the profession. This situation also leads to the lack of knowledge and skill of social workers working in the field. This can be assessed in terms of the most important risk factors for the future of the social work. According to the distribution of the academicians at the undergraduate level, $36 \%$ are from social work based and $64 \%$ are from other disciplines outside social work field.

Most of the social workers are currently working in the public sectors such as the Ministry of Health (mainly hospitals), Ministry of Family and Social Policy (e.g. nursing homes, kindergartens, love homes, children's homes, care and social rehabilitation centers, nursing and rehabilitation centers, child and youth centers, physical therapy centers, elderly care centers, social service centers, family counseling centers), and Ministry of Justice (family and child courts, probation, prisons, child education homes). In the private sector, they work in places such as elderly care and rehabilitation centers, nursing homes, kindergartens, family counseling centers. They are also involved in non-governmental organizations such as UNICEF and World Health Organization. Recently, there has been an active work opportunity in non-governmental organizations, especially those working for asylum-seekers and refugees.

Unemployment is not a problem for social work graduates until 2016, but employment for social workers has become a major problem because of the large number of students who graduated from open education departments and departments opened uncontrollably. According to TSI (Turkish Statistical Institute) 2016 statistics, the highest unemployment rate among higher education graduates emerged in the field of social work with 24 percent (http://www.kamubiz.com).

\section{Master's Degree Education}

Social work education in Turkey began at undergraduate level in 1961. Just as in undergraduate education, postgraduate social work education could not become widespread for a long time. Social work department (Sosyal çalışma) of Hacettepe University was passed the history as the first program that started the graduate and doctorate programs in social work field in Turkey. It is known that a total of eight academician have completed their graduate and doctorate. In 1983, both programs of social work were merged. In 1983, a new master's degree "Social Work" program was opened in the Department of Social Work under the Institute of Social Sciences at Hacettepe University (Karataş \& Erkan, 2005) and has graduated many students to date.

Postgraduate education, which was given only by Hacettepe University until 2010, has started to increase along with postgraduate programs opened by other universities from this year forth. Social work master's degree program is available at 17 universities in Turkey. Non-thesis master program is also available in 9 universities.

Given the global reach of the profession, social work education represents diversity in programme designs, course contents, curricula, practice settings, student profiles, client populations and services. Although social work training levels are similar in terms of postgraduate programmes, their structure and duration, there are however, significant differences.

Master of social work aims to prepare the graduates for the advanced practice in the fields of social work. The overall objective of the Master's Degree in Social Work Programs (MSW) is to provide education on the global level and also to 
train social work scientist experts who are open to improvement and able to communicate and interact with his colleagues and who have reached sufficient knowledge and skills in the field of social work, played an active role in the solution of social problems and has adopted the principle of adherence to the ethical rules.

The curriculum content of the graduate program in Turkey varies from university to university and even from institute to institute. Master's Degree programs provide education under the institutes of social sciences and health sciences in some universities. Master's Degree programs in Turkey are given in two forms as with thesis and non-thesis. The duration of a Master's Degree program with thesis is four semesters. The courses are taken in the first two semesters, and master's thesis is prepared in the other two semesters. Students who do not graduate with social work license can commence regular graduate program after receiving the preparatory program. The condition of being a graduate of a social work is not generally required in the application requirements to master of social work degree programs. Because the number of social work degree graduates is very low. According to data of the Association of Social Workers in 2015, this number is around 4,500. Making practice is also required in master's degree program with thesis at social work institutions one day per week during two semesters. In order to graduate from the Master's degree program, it is obligatory to complete at least 120 ECTS.

Non-thesis master's degree programs consist of two semesters. A thesis is prepared by the student at the end of the two semesters. The graduates of non-thesis master's degree programs have no right to apply to doctoral programs. It is required to have a master's degree with thesis in order to apply for doctoral programs. Those who have a non-thesis master's degree gain the title of scientist as well. The admission requirements to master's degree social work programs vary according to each university in Turkey. However, except for ALES which is mandatory, the criteria, such as foreign language, being a graduate of social work program, the graduation grade depend on the decision of the universities. Besides it is not yet to have a specialization in the master's field. Specifically, master's degree programs, such as family counseling and clinical social work provide opportunities for specialization in some universities.

$25 \%$ of the courses in the graduate curriculum consist of elective courses in accordance with the Bologna process. Graduates are having a Master of Science degree in social work. However, those who are not originated of social work graduate program are not able to work with the title of social worker. In our country, the title of profession is acquired by training at bachelor's degree. That is, professional title cannot be won with master's degree.

Social work education in Turkey started in 1961 and has been at the bachelor's level until 1983. Since 1983, master's degree "Social Work" program was opened in the Department of Social Work under the Institute of Social Sciences at Hacettepe University (Karataş \& Erkan, 2005) and has graduated many students to date. Social work master's degree program is available at 12 universities in Turkey. Non-thesis master program is also available in 9 universities.

The Council of Higher Education has standardized Core Competencies of Master of Social Work Programs in Turkey (Academic Weighted) on the basis of the information (theoretical and factual level), skills (cognitive and practical) and competence (the ability to work independently and to take responsibility, learning, specific communication and social skills and field competency).

\section{Doctoral Education}

The first $\mathrm{PhD}$ degree in social work in America awarded by Bryn Mawr College in 1920 (Kurzman, 2015) After 67 years, the establishment of the first doctoral degree program of social work in Turkey awarded by Hacettepe University in 1987. Hacettepe University became the first and unique establish a doctoral degree program of social work in Turkey from 1987 to 2010 .

The doctoral degree in higher education is the termination of formal degree levels of educational achievement. Graduates of doctoral degree programs are expected to become leaders and thinkers in their discipline, in their communities, and in the larger society. Since 1983, doctoral degree "Social Work" program was opened in the Department of Social Work under the Institute of Social Sciences at Hacettepe University (Karataş \& Erkan, 2005) and has graduated many students to date.

Doctoral education is given in Turkey at seven (7) universities total. The three of them are in Ankara, one of is in Turkey, in Kocaeli, in İstanbul and in Yalova. Besides, the integrated doctoral program at Hacettepe University consists of 10 terms. The master and doctoral programs are combined in integrated doctoral program and is awarded the title of doctor after the graduation of the program.

The most important of the admission requirements of the $\mathrm{PhD}$ program is to perform master's degree in social work. However, some universities also accept applications from other disciplines. Although the curriculum of doctoral programs in each university is different, they have adopted a generalist approach of social work in their curriculum. Besides the theoretical courses, practice is also mandatory in the $\mathrm{PhD}$ program.

Doctoral programs consist of eight semesters. The students have to take a "Qualifying Examination" when they complete their coursework in the first four semesters. Qualifying exam consists of written and oral interviews. Doctoral students must be able to pass a written exam and an oral interview to be successful. A thesis monitoring committee is created for students who pass the qualifying exam. Thesis Committee consists of three faculty members. Then a research proposal is prepared for doctoral dissertation, presented to the monitoring committee and after acceptance 
the student begins to implement his dissertation. Dissertation monitoring committee meets at least twice a year, when necessary and the studies of students are discussed. After the completion of a thesis, the student enters thesis dissertation defense exam and defends his dissertation against a jury consisting of five faculty members. Student assumes the title of doctor after a successful dissertation defense. Field Practice is also required in a doctoral program at social work institutions one day per week during two semesters. It is also necessary to complete at least 240 ECTS to get a doctoral degree.

\section{Discussion}

As a result, a number of risk factors have emerged that need to be addressed and evaluated in relation to the current state of social work education, which is believed to affect or be affecting the profession and professionals. These risk factors are;

1. Late offering of social work master and doctoral programs and the acceptance of very few students: This has resulted in a small number of social work academicians and the number of trained social work academicians. This also means there are needs for academicians' in social work schools, which are rapidly growing in number, Nowadays, the number of social work academicians (professor, associate professor and assistant professor) is around 55. Not each department has even one academician according to this. Of all the academicians in all social work schools, $36 \%$ are of social work origin and $64 \%$ are of other disciplines. However, the majority of these $36 \%$ are working in social work schools in Ankara and Konya. In addition, the opening of social work bachelor's, masters and doctoral programs is one of the biggest threats to the current status and future of the social work profession, although there are no academicians of social work origin in these programs. Students graduated from these programs learn from different professionals such as sociologists, psychologists, theologians, economists, business administrator, public administrators, philosophers, PDR (Guidance and psychological counseling)s, English language and literature, international relations, historians, medicine physician and economists. This situation causes the graduates of social work to be inadequate in the field. This also negatively affects the future of the social work profession and the attitude of the society and other professionals to social work profession.

2. Opening of two-year degree programs: Associate degree programs have been opened in 50 universities in Turkey. Although the job description of these associates degree programs have not been defined, the fact that number of these programs and unemployed graduates have increased dramatically since 2012 is an important question about social work education. It is not clear what students will graduate from these programs and which titles to win. Curriculum programs vary from universities to universities. It is also not recognized by social workers and public authorities. The professional organization totally opposes the perception of these associate degree programs as a subdivision of social work and does not accept it as a social work application. In addition, they can also make transitions in this undergraduate program to bachelor's degree programs with external transfer exam. The graduates of this program also raise the likelihood of unemployment in the area of social work. These departments continue to be opened uncontrollably. The number of these programs continues to increase despite all the efforts of our professional organization. This situation will continue as long as the higher education institution does not intervene in this uncontrolled situation. The factors such as excessive quotas, not being included in international social work education standards, perception as associate degree of social work bachelor's degree program due to similarity of its' name and curriculum, ambiguity in mission, purpose and scope, confusion of post graduate title, qualification of academic staff giving education in very small districts and, internship place problem are important problems that come to mind about these sections.

3. Opening of open education programs: One of the greatest risks for social work education is the opening of "open education programs". Free of compulsory attendance, having chance to be a social worker with fewer points and with less labor and cost, possibility of completion of bachelor's degree by transfer within programs easier, relatively easier tasks and exams, lack of practical conditions like formal education, being advantageous of students of open education programs in terms of preparing for civil service exam compared to those of formal education who are preparing for classes and exams It also provides the advantage of getting education for working individuals who cannot continue to formal training. However, the most important problem is high quotas, low quality of education and that is the graduated students are unqualified and inadequate in terms of knowledge and skills because of the fact that social work education can only be provided with formal education as more qualified. Curriculum programs have a theoretical weighted structure. On the other hand, the practical side of the social work profession is an indispensable factor. The fact that three different universities have high quotas imposed on them negatively affects the employment situation in the 
social work field and causes the social workers to be unemployed.

4. The rapid increase in the number of departments: The first social work department in Turkey was opened in 1961 and the second department was opened in 1967 and in 1983, these two sections were merged into a single department until 2006. Since 2010 , the number of social work departments has increased dramatically and uncontrollably, and today this number has reached 55 with the evening education departments. The number of social workers who graduated from the schools in Turkey between 1961 and 2015 is around 5000, according to the data from the association of social workers. However, nowadays, the increase in the number of departments has also increased the number of graduates. The increase in the number of graduates has caused employment problems. Until 2016, the number of unemployed social workers was low while the number of unemployed social workers was very high with graduates of 2017. According to the estimates, it is expected that the number of graduates will be around 14.000 by the end of 2017 and this number will be around 32.000 by 2020 (these numbers are calculated considering the quotas of the existing schools). In addition, the opening of two social work departments at the same university under both faculty and college is another problem.

5. Horizontal and vertical transitions: Another risk in terms of the social work profession is the vertical transition from different associate degree programs directly to social work degree programs. For example, horizontal transitions can be made from associate degree programs in such fields as firefighting and fire safety, security, social security, intelligence, air defense, occupational health and safety, and social sciences, to social work bachelor's degree programs. Students who completed the first two years in different areas can begin in the third year without taking the basic courses of social work departments. Therefore, they become qualified by training in social work only for two years, and educated outside of academicians of social work origin. Problems arise in terms of knowledge, skills and ethics. It causes the growth of unskilled, incompetent and inexperienced social workers. This risk factor is another of the most important threats to the existence and future of the profession. In addition, vertical transfers can be made to four-year social work open education programs from emergency health care, forensic medicine, oral health, nursing, physiotherapeutic, midwifery, radiotherapy and optics which are associate degree of health sciences.

6. Creation of different curriculum programs: Due to the majority of academicians from different disciplines in social work schools, each profession group prepares a curriculum with its own weight. Some of them prepare a curriculum and content focused on generalist social work education, some method-focused, some sector-focused, some self-focused. This prevents training in social work standards recognized internationally. The majority of these schools are also not members of the association of international social work schools. Consequently, it is hard to train social workers who have common knowledge, skills and ethical values.

7. Lack of accreditation standards: In our country, there has not been an accreditation process regarding social work programs in which applications such as curricula, programs have been standardized. In addition, an organization to accredit social work schools has not yet been established. In the same way, standardized training practice standards have not been developed.

\section{Conclusions}

Social work education started in the United States and in Europe since the beginning of the 1900s. Social work education in the United States and Europe was given at bachelor's degree in 14 universities in 1910. Social work education started in Latin America (Argentina and Chile) in 1920, South Africa in 1924, India in 1936 and Australia in 1940 (Rajendra, Venkat and Channaveer, 2014; Karataş ve Erkan, 2005). In the 1960s, social work education was given in 150 schools in the USA and 41 schools in France (Payzin, 1961). According to the United Nations, social work education was given under social work department in 373 schools in 46 countries at the same period around the world (Sedky, 1961; Karataş \& Erkan, 2005) but, social work education at bachelor's degree first started in 1961 in Turkey.

The late beginning of the social work education in Turkey and giving education in only one department until 2002 have led to a limited number of social workers in the field. According to the association of social workers, the number of social workers graduated from social work department is around 5,000 (including pensioners) in Turkey as of 2015. Also, not all of them work as social worker in the field. In contrast, the number of social workers is 95,000 in 1960 and 595,000 in 2006 in the USA. By the end of 2016 the number is estimated to increase by $22 \%$ (Zastrow, 2010). When the number of social workers trained as social worker and work in the field are compared, the number in our country is very insufficient. This fact reveals the need for more schools of social work in Turkey. In addition, as required by Turkey's European Union membership process between the years 2003-2010 and with the impact of the obligations of Turkey and responsibilities to meet, it has emerged as an obligation of opening of schools of social work in order to train more social workers. Social workers began to be employed 
especially in family and juvenile courts, and in the field of probation and other social services quickly.

Social work schools in which no academician with a social work background were opened to meet the requirements of social work field since 2009 rapidly and uncontrolled. This case is still under discussion today. According to the state of social work schools which are increasing rapidly and in an uncontrolled way; 55 bachelor's degree, 12 master's thesis, 9 non-thesis master's program and 7 doctoral programs are available in social work program as of the end of 2016. But the most important uncontrolled situation is the opening of undergraduate programs at distance education level and graduate programs and curriculum of these programs are not parallel with the formal education curriculum. In addition, giving thousands of students the right to enroll caused the increase in the number of graduates and resulted to employment problems. The practice part of these distance education programs is problematic. It is not given importance to practice like formal education schools. Also, there are no or not many social work institutions in the provinces in which social work departments were opened. This situation leads to a lack of practical aspect of social work.

Social work education is given at bachelor's, master's, and doctoral level with regard to the international principles and standards for social work education. Therefore, opening of social work undergraduate program does not conform to international standards. However, it is strongly needed of labor force who will be employed as caregivers for caring of children elderly and persons with disabilities who are in need of nursing, and employed as intermediate staff who will conduct documents, correspondence and other clerical duties. Associate degree level Field competencies prepared at undergraduate level in accordance with Turkey National Qualifications Framework for Higher Education was conducted in line with this concept. However, the name of any undergraduate program at this level (social work) should not be determined in a manner to cause confusion with the name of the bachelor's degree program (social services) (Alptekin, 2016).

In practice, the situation has been this way and has already led to serious confusion. Therefore, it is better to acknowledge associate's degree programs named now as "Social Work" in Turkish higher education system as programs serving for growing intermediate manpower which could be described as "social secretary" needed in social services sector rather than to perceive as associates of social work bachelor's degree program. The people who are trained in associate's degree programs are in a relationship of equal distance with all licensed professionals (social workers, psychologists, teachers, child development, etc.) actively involved in social work sector. Thus, the people who have graduated from this program are considered to have vertical transfer rights to these areas.

To what extent that courses taken in associate's degree programs meet the bachelor's degree program should be considered in the context of an orientation program to be made by the departments. Although curriculum contents of associate's degree programmes are organized similar to the curricula of social work bachelor's degree programs, it is a known fact that those people cannot work with clients like as a social worker trained at bachelor's level does. Trained attempts in the field of education are a reality that cannot work with clients who know as a social worker. Moreover, it is not yet determined what title will take the students who graduate from this program (Alptekin, 2016).

That the graduate programs in the field of social work remained limited to a single university in Turkey for many years has led to incapability to meet the need of academician. This situation emerges as one of the biggest obstacles in front of us in training social work academicians. The number of employees and social work origin lecturers in the departments of social work in Turkey is only around 55 as of the beginning of 2016. This situation is the proof of social work education is provided by lecturers not of social work origin.

Social work programs given at undergraduate, graduate and doctoral level in the USA, European countries and other countries are accredited by CSWE (Council on Social Work Education), IASSW and accreditation bodies at the local level. A CSW is the accrediting association for all undergraduate and graduate schools of social work located in the United States. CSWE is working to improve the quality of education in social work programs by setting standards for undergraduate and graduate levels in social work education. Students learn what the national standards are in the education program accredited by CSWE, so that they are trained with the aim of solving problems of each applicant system and to create change as well as social and ethical values of social work by working with individuals, families, groups, organizations and the community. These students are often advantageous position to be employed after graduation. Because social welfare institutions prefer to run who have graduated from accredited programs (Segal, Gerdes \& Steiner, 2007: 7; Zastrow, 2010).

There are social work master's degree program in a total of 14 universities in Turkey. It is available non-thesis master programs in 9 universities. In 2002, it was also available in the USA 432 social work bachelor's degree programs, 146 master's programs and 67 doctoral which were accredited (Feldman, 2002). However, the number of bachelor's degree program was 509 and master's degree program was 245 accredited by CSWE (Council on Social Work Education) by February in 2016 in the United States; while the number of bachelor's degree programs who applied to be accredited is 15 and the number of master's program is 16 (http: //www.cswe.org/accreditation.aspx, 2016).

In Turkey, many schools are members of the International Association of Schools of Social Work (IASSW). However, any bachelor's, master's and doctoral programs which are accredited nationally or internationally (International Association of Schools of Social Work (IASSW) are not 
available in the field of social work.

When students were admitted to the social work academy opened in 1961, they were subjected to various tests and after an interview then proper students were selected. Today placement is made to social work departments in accordance with points taken today in the Student Selection Exam. They are not subject to any interview or test. Therefore, each student taking the adequate score on the student selection examination can be accepted into the department. However, this is problematic in terms of career. For example, that some students work as social workers can be a problem in terms of they have some mental and behavioral problems and are unsuccessful in developing relationships with other people. In our country, while students are making career choices, there is not any exam or interview questioning students' qualifications and competencies at the point whether they are able to practice the profession or not. Therefore everyone who became successful in the university entrance exam and in completed courses has right to do that job. In this case, if the personality of the individual is not suitable for that the profession, the applicant is the one who is the most affected negatively by this situation.

In addition, while students graduate they are not subjected to any examination or interview which demonstrates their proficiency and competencies. Therefore, the student has the authority to make his profession with a diploma grade. In contrast, we believe it is necessary to make a practical exam and an interview which reveals the qualifications and competencies of social workers. Also currents quota are increased by admitting students to formal education at least about 500 students each year from irrelevant programs (private security and protection, air defense, security intelligence, fire brigades and civil defense, munitions and ammunition destruction and so on.) with the External Transfer Exam (ETE) (Alptekin, 2016). These students who make transition from these irrelevant departments to social work bachelor's degree programs with the External Transfer Exam (ETE) are launched education from 3rd class. This fact causes graduates of social work to become lack of knowledge, skills and competencies and accordingly to increase the number of incompetent professionals.

The majority of social workers graduated in Turkey are employed in public institutions. But an examination is applied to be a civil servant. All social workers graduate from formal and open faculty enter the same examination. It is in favor of students graduated from open faculty that the questions in civil service examination consist of general knowledge, mathematics and Turkish subjects but do not include content knowledge. If it is asked content knowledge questions in the examination, it is assumed that it will occur the difference between formal education and distance education, and this could arise a vice versa situation in favor of formal education. Distance education exams and curriculum are simpler and easier than formal education. The average grade of distance education students is higher but they are thought to be lack of internalizing basic skills, information and value basis of social work. To be Therefore, we believe that giving social work education with distance education method is not a proper.

One of the most striking elements of the curriculum content in social work education is the practice phase. The importance and weight of practice in each semester has maintained its importance in the curriculum. In this regard it is taken the standard of International Association of Schools of Social Work as the basis. However, the issues such as how the practice will be carried out, in which class, when and where vary from program to program (Karatas \& Erkan, 2005). Schools that have asocial origin lecturers within the curriculum trying to do in accordance with this standard, but it cannot be said that others acted in a way appropriate this standard. This illustrates the differences in the field.

An association or organization which schools of social work in Turkey affiliated with is not available by 2016 . In this situation social work education exists within the national system of the Turkey, but the content, curriculum and practice may differ from one university to another. There are no standard patterns of education for social work in Turkey. Association of Schools of Social Work was established by the beginning of 2016 in Turkey to standardize social work education and to make and provide cooperation, coordination and joint curriculum studies between the schools of social work. This association has adopted the working principle of the International Association of Schools of Social Work.

The first doctoral program in social work was opened in 1920 in the United States at Bryn Mawr College. However, in Turkey, master's and doctoral level education in social work was opened a half age later. That the graduate programs in the field of social work remained limited to a single university in Turkey for many years has led to incapability to meet the need of academician.

This situation emerges as one of the biggest obstacles in front of us in training social work academicians. The number of employees and social work origin lecturers in the departments of social work in Turkey is only around 50 as of the beginning of 2016. This situation is the proof of social work education is provided by lecturers not of social work origin.

One of the most important problems is to open master and doctoral programs in the universities with academicians who have not graduated from any of the undergraduate, graduate and doctorial social work education.

In Turkey, social work education as in the point reached today is extremely messy appearance. Academicians are assigned in social work education belonging to many different and uninterested disciplines (business, history, theology, English language and literature, industrial engineering, etc.) New departments can be opened in the cities having unsuitable infrastructure for this training or even can be opened in the presence of academicians trained in bachelor's or master's degree. Many graduates are given from these departments opened one after another in an unstructured and non-foundational way. 
The distance education departments in Turkey should be either closed or go to limit quota. An accrediting agency that accredited schools of social work should be established or should be taken of the accreditation from an international organization. A common curriculum which is in accordance with international standards should be established in schools providing social work education. The measures necessary to increase the number of academicians should be taken and the number of doctoral programs should be increased.

The quota placement of schools not including academicians with social work origin should be stopped or turned off. Associate degree programs should be reorganized as a personnel training program oriented to the objective that can help all disciplines of social work, not specifically as an area of social work. The procedures of transition to the social work departments from irrelevant departments with the External Transfer Exam (ETE) should be canceled section of the vertical transfer part disinterested examination procedures should be canceled.

The opening of new social work departments in universities and provinces where there are no social work institutions and foundations. The number of graduates in the field of social work is thought to be increased in the coming years due to the increasing number of departments and distance education, necessary measures and precautions should be taken towards to employment issues.

\section{REFERENCES}

Addams, J. (1893). The subjective necessity for social settlements. In H. C. Adams (Ed.), Philanthropy and social progress (pp. 1-26). New York, NY: Thomas Y. Cromwell. To link to this article: http://dx.doi.org/10.1080/10437797.2016.1117916.

Alptekin, K., Topuz, S. \& Zengin, O. (2014). Türkiye'de sosyal hizmet eğitiminde mevcut durum: tespitler, analizler ve öneriler. E. Atamtürk ve E. Yaman (yayına hazırlayanlar). (İçinde) Sosyal hizmet sempozyumu 2013: Türkiye'de çocuğun refahı ve korunması: kapsayıcı bir yaklaşım arayışı, ss.353-366. Sempozyum Bildirileri (elektronik basım). Kocaeli.

Alptekin, K. (2016). Türkiye'de sosyal hizmet ĕgitimi, Nobel Yayınevi, 1. Baskı, Konya.

Aydemir, İ. \& Gökçearslan, E. (2011). Reconstruction of medical social work in Turkey, Emerging Issues In The Applied Sciences, Academic Book, Chapter 4,: 276- 292, Baku, Azerbaijan.

Bulut, I. (2003). A generalist approach in social work education in Turkey, Social Work \& Society, Volum1, No: 1.

Chandler, S. (1999). Prising open that old prejudiced door: African-Americans, poverty, and social work in the early twentieth century. In G. Lowe, \& P. Reid (Eds.), The professionalization of poverty: Social work and the poor in the twentieth century (pp. 105119). Piscataway, NJ: Aldine Transaction. To link to this article: http://dx.doi.org/10.1080/10437797.2016.1117916

Çengelci, E. (1998). Sosyal hizmetler ve çocuk esirgeme kurumu. Ankara: Aydınlar Matbaacılık.
Çakmakli, K. (1976). Türkiye'de sağlık hizmetlerinin bütünleşmesinde tıbbi sosyal hizmetin önemi." İstanbul: İstanbul Üniversitesi Tıp Fakültesi, Tıp Bilimleri Doktora Tezi.

Çetinsaya, G. (2014). Büyüme, kalite, uluslararasılaşma: Türkiye yüksekögrretimi için bir yol haritast. Ankara: Yükseköğretim Kurulu Yayın No: 2014/2. Erişim: 20.10.2015, https:// www.yok.gov.tr/documents/10279/2922270/Büyüme+Kalite+Ulus lararasılaşma+ cetins aya-19x27-12,5forma.pdf/

Duyan, V. (1996). Sağllkta psiko-sosyal boyut (tıbbi sosyal hizmet). 72TDFO. Ankara

http: //www.cswe.org/accreditation.aspx, 2016. Educational Policy and Accreditation Standards (EPAS) for baccalaureate and master's cocial work programs (2015). Council on Social Work Education (CSWE). Retrieved January 28, 2016,

http://www.cswe.org/File.aspx?id=81660

Feldman, A.R. (2002). Developments in social work education in the United States and their implications for Turkish social work education, Sosyal Hizmet Sempozyumu, 2002, "Sosyal hizmet eğitiminde yeni yaklaşımlar, Hacettepe Üniversitesi, Sosyal Hizmetler Yüksekokulu Yayını, Yayın No: 17, ss: 29-36.

Gibelman, M. (1999). The search for identity: Defining social work past, present, future. Social Work, 44, 298-310. doi:10.1093/sw/44.4.298.

Gökçearslan, E. (2009). Social work profession and social work education in Turkey, Procedia Social and Behavioral Sciences 1 (2009) 2063-2065

http://www.kamubiz.com/sinavlar/is-bulma-ihtimali-en-yuksek-me slek-veterinerlik-en-dusuk-ise-sosyal-h687.html, 2017.

IFSW (International Federation of Social workers), http://ifsw.org/policies/definition-of-social-work/, 2017

İyicil, F. (1963). Sosyal hizmet okulları ve öğrenci seçme işi, Sosyal Hizmet Dergisi, Cilt 1, Say1 9.

Karataş, K. \& Erkan, G. (2005). Türkiye'de sosyal hizmet eğitiminin tarihçesi. Ü. Onat (yayına hazırlayan). (İçinde) Sosyal hizmet sempozyumu 2002: sosyal hizmet eğitiminde yeni yaklaşımlar, ss. 112-133. Ankara: Aydınlar Matbaacılık Ltd. Ști.

Koşar, N.G., ve Tufan, B. (1999). Sosyal Hizmetler Yüksekokulu tarihçesine genel bir bakış. N.G. Koşar (editör) ve V. Duyan (editör yardımc1s1). (İçinde) Prof.Dr. Sema Kut'a armağan: yaşam boyu sosyal hizmet, ss. 1-20. Ankara: Hacettepe Üniversitesi Sosyal Hizmetler Yüksekokulu, Yayın No: 004.

Kuntbay, G. (1962). Sosyal hizmet mesleğini tanıyalım, Sosyal Hizmet Dergisi, Cilt 1, Say1 5.

Kurzman, Paul. A. (2015). The Evolution of Doctoral Social Work Education, Journal of Teaching in Social Work, 35:1-13, 2015

Kut, S. (2005). Türkiye'de sosyal hizmet mesleğinin eğitimi. Ü. Onat (yayına hazırlayan). (İçinde) Sosyal hizmet sempozyumu 2002: sosyal hizmet eğitiminde yeni yaklaşımlar, ss. 9-13. Ankara: Aydınlar Matbaacılık Ltd. Şti.

NASW (National Association of Social Workers. (1995). Significant dates in social welfare history. Encyclopedia of social work (Vol. 3, 19th ed.). Alexandria, VA: NASW Press.

ÖSYS (Öğrenci Seçme se Yerleştirme Sistemi) -2016 Guide for Assessment Selection and Placement Center -Yükseköğretim Programları ve Kontenjanları Kılavuzu, (2015). 
ÖSYM (Ölçme, Seçme ve Yerleştirme Merkezi), 2016 Guide for Assessment Selection and Placement Center, Ankara. Retrieved Junary 06, 2016,

http://www.osym.gov.tr/belge/1-23560/2015-osys-yuksekogretimp r ogramlari-ve-kontenjanlari-ki-.html

Guidenca for Student Selection and Higher Education Programs and Quotas, July, 2017,

http://dokuman.osym.gov.tr/pdfdokuman/2017/OSYS/OSYSKON TKILAVUZU22062017.pdf

Payne, M. (2005). The origins of social work: continuity and change. Houndmills, Basingstoke, Hampshire; New York: Palgrave Macmillan,

Payzın, S. (1961). Sosyal hizmetler yüksekokulu amaçları, Sosyal Hizmet Dergisi, Cilt 1, Say1 2.

Rajendra, B., Venkat, P., and Channaveer, R.M. (2014). Social work education in India and Australia, International Journal of Social Work and Human Services Practice, Horizon Research Publishing Vol.2. No.6 Dec, 2014, pp. 311-318.
Sedky, M. (1961). Sosyal Hizmetler Akademisi Konuşması, Sosyal Hizmet Dergisi, Cilt 1, Say1 4.

Segal, E.A., Gerdes, K.E. \& Steiner, S. (2007). An introduction to the profession of social work: becoming change agent. 2nd edition. Belmont, CA: Thomson--Brooks/Cole.

Tratter, W. (1998). From poor law to welfare state: A history of social welfare in America (6th ed.). New York, NY: Free Press. To link to this article:

http://dx.doi.org/10.1080/10437797.2016.1117916

Uluğtekin, S., Tomanbay, İ., Cılga, İ., Arıkan, Ç., Mavili-Aktaş, A., İl, S., Küçükkaraca, N., Karataş, K., Demiröz, F., Kars, Ö. (2002). Akademik yönden yeniden yapılanma önerisi. Hacettepe Üniversitesi

Zastrow, C.H. (2010). Introduction to social work and social welfare: empowering people. Belmont, CA : Thomson/Brooks/Cole 